\title{
There is no disease but the patient: Medical observations on Hermann Hesse's Novel Beneath the Wheel
}

\section{Hastalık yolk, hasta vardır: Hermanı Hesse'niin Çarkklar Arasında Romanı Üzerine Tibbi Değerlendirmeler}

\section{Halil TEKINER ${ }^{a}$}

Studying narrative medicine has increasingly been considered a useful tool in medical education because it offers a more holistic approach to health care, encourages empathy, provides enriched ethical perspective, and promotes better understanding between clinician and patient (1-2). In hoping to contribute to this stillgrowing field, I would like to present a medical condition depicted in an early literary piece by Hermann Hesse (1877-1962), a famous German author who was awarded the Nobel Prize in 1946.

In his 1906 novel Beneath the Wheel, later reissued as The Prodigy, Hesse criticizes the conventional educational system's focusing solely on students' academic achievements while neglecting their personal and emotional development. The book tells the story of Hans Giebenrath, an exceptionally gifted boy from a small village, who succeeded in entering a respected seminary. After becoming emotionally attached to a rebellious and less academically assiduous classmate, Hans begins questioning the pressure he has long experienced with regimens of heavy studies. Torn between self-affirmation and self-destruction, he begins to fail in his courses and is ultimately expelled from the seminary due to a nervous breakdown (3).

Throughout the novel, we see Hans suffering from chronic headaches triggered by high levels of stress or anxiety, particularly during exam periods. These headaches are also accompanied by several other conditions, such as change in temperament (p.19), lack of appetite (p.19), nightmares or difficulty sleeping (p.19, 143, 188), temporary motor weakness (p.124, 139, 211), concentration problems (p.139), dizziness (p.139, 188, 197, 211), and suicidal thoughts (p.163) (3). None of these conditions, however, is taken seriously by his teachers or his family. Even a district physician tends to underestimate his difficulties as a "slight nervous disorder, due principally to his growing" or a "passing condition-light dizzy spells" (p.162). Ignoring Hans's personal life beyond his medical conditions thus ushers the tragic end of the novel (3).

It is of note that several conditions described above are likely in parallel with the clinical features of some young migraine sufferers who tend to be high achievers. Interestingly, Hesse experienced similar conditions as a teenager in the early 1890 s when he was expelled from school and flirted with suicide (4).

Like his other works dealing with several diseases (5), Beneath the Wheel is an interesting literary piece with an autobiographical slant and an early example of patient narratives in literary fiction in the previous century. It might therefore be advisable to be included in medical humanities courses to better illustrate the ethical value of patient-centred care as epitomized in the Hippocratic aphorism: "There is no disease but the patient."

Conflict of interest: The author has nothing to disclose.

${ }^{2}$ Ph.D., Assoc. Prof. Dr., Department of the History of Pharmacy, Erciyes University Faculty of Pharmacy, Talas 38280 Kayseri, Turkey, 四 htekiner@erciyes.edu.tr Gönderim Tarihi: $06.10 .2018 \bullet$ Kabul Tarihi: 06.10.2018 


\section{References}

1. Greenhalgh T, Hurwitz B. Narrative based medicine: why study narrative? BMJ 1999; 318(7175): 48-50.

2. Charon R. Narrative Medicine: Honoring the Stories of Illness. Oxford: Oxford University Press; 2006.

3. Hesse H. Beneath the Wheel. trans: M Roloff. New York: Bantam Books; 1981.

4. Mileck J. Hermann Hesse: Biography and Bibliography. vol 1. Berkeley: University of California Press; 1977.

5. Briët MC, Haan J, Kaptein AA. Hermann Hesse and L: two narratives of sciatica. Clin Neurol Neurosurg 2012; 114(1): 9-11. 